\title{
Use of Complementary and Alternative Medicine in Patients with Gynecologic Cancer: a Systematic Review
}

\author{
Dercan Akpunar ${ }^{1 *}$, Hatice Bebis ${ }^{1}$, Tulay Yavan $^{2}$
}

\begin{abstract}
Purpose: Research carried out with gynecologic cancer patients using CAM was reviewed to provide a source for discussing which CAM method is used for which purpose, patients' perceptions on the effects/side effects occurred during/after using CAM and their sources of information regarding CAM. Materials and Methods: This literature review was carried out for the period between January 2000 and March 2015 using Scopus, Dynamed, Med-Line, Science Direct, Ulakbim, Research Starters, Ebscohost, Cinahl Complete, Academic Onefile, Directory of Open Access Journals, BMJ Online Journals (2007-2009), Ovid, Oxford Journal, Proquest Hospital Collection, Springer-Kluwer Link, Taylor \& Francis, Up To Date, Web Of Science (Citation Index), Wiley Cochrane-Evidence Base, Wiley Online Library, and Pub-Med search databases with "complementary and alternative medicine, gynecologic cancer" as keywords. After searching through these results, a total of 12 full length papers in English were included. Results: CAM use in gynecologic cancer patients was discussed in 8 studies and CAM use in breast and gynecologic cancer patients in 4 . It was determined that the frequency of CAM use varies between $40.3 \%$ and $94.7 \%$. As the CAM method, herbal medicines, vitamins/minerals were used most frequently in 8 of the studies. When the reasons why gynecologic cancer patients use CAM are examined, it is determined that they generally use to strengthen the immune system, reduce the side effects of cancer treatment and for physical and psychological relaxation. In this review, most of the gynecologic cancer patients perceived use of CAM as beneficial. Conclusions: In order that the patients obtain adequate reliable information about CAM and avoid practices which may harm the efficiency of medical treatment, it is recommended that "Healthcare Professionals" develop a common language.
\end{abstract}

Keywords: Complementary medicine - alternative medicine - gynecologic cancer

Asian Pac J Cancer Prev, 16 (17), 7847-7852

\section{Introduction}

According to the definition made by National Institutes of Health (NIH), complementary and alternative medicine (CAM) is "a broad field of medicine which includes all medical services, methods, practices and accompanying theories and beliefs except for the healthcare system which is politically dominant in a society or culture in a specific period of time" (Karayagiz-Muslu and Ozturk, 2008; Wieland et al., 2011).

CAM is based on Ancient Chinese and Ayurvedic Medicine. Although it has a long history, it has become popular in the world rather recently. While use of CAM in developed countries is $42.1 \%$ in the USA, $48.2 \%$ in Australia, 49,3\% in France and $70.4 \%$ in Canada; in developing countries it is $71 \%$ in Chile, $70 \%$ in China, $40 \%$ in Columbia and $80 \%$ in African countries (Turan et al., 2010). For that reason, more scientific research and evidences are required in relation to the efficiency/ side effects of the use of CAM. The deficiency in the literature was noticed and NCCAM (National Center for Complementary and Alternative Medicine) was founded within NIH in 1998. The aim of this center is to investigate the reliability and efficiency of CAM practices and provide participation in complementary and alternative treatments efficiency of which is scientifically proven (Manheimer and Berman, 2003).

NCCAM classified CAM methods under five different categories as mental and physical practices, alternative medicine practices, biological treatments, manipulative and physical practices and energy therapies (bio-field and bio-electromagnetic) (Manheimer and Berman, 2003) (Table 1).

One of the diseases in which CAM is used commonly is cancer. The incidence rate of cancer is increasing rapidly in the world and our country. According to 2012 data of GLOBOCAN and International Agency for Research on Cancer (IARC), 14,1 million new cancer cases occurred and 8.2 million people died due to cancer (www.who. int, 2015). The increase of cancer incidence in the world and our country depends on the improvements in early diagnosis and treatment opportunities (chemotherapy, radiotherapy and surgical methods) and the survival period of the patients is extended. Patients want to extend this 
Dercan Akpunar et al

period more, reduce the side effects of the treatments and have a quality life using CAM. In studies investigating the use of CAM by cancer patients, it is indicated that 3050\% use CAM (Lee et al., 2000; Pud et al., 2005; Scott et al., 2005; Upchurch et al., 2005; Verhoef et al., 2005).

Women have played a role in patient care throughout the history and it is seen that they are able to easily carry out many practices discussed in the scope of CAM (herbal treatments, massage, prayer, etc.). In that respect, among the factors which influence the use of CAM, gender has an important place as well as age and education. As indicated in the studies, women use CAM in all stages of their lives and CAM methods vary according to the problems they encounter (Gungormus and Kiyak, 2012). In the literature, it is seen that women diagnosed with gynecologic cancer use CAM frequently (Upchurch and Chyu, 2005; Akyuz et al., 2007; Amanak et al., 2013). When studies on CAM are reviewed, it is determined that most of the patients cannot explain the reason why they use CAM clearly and do not have any information on the effects/side effects of using CAM (Verhoef et al., 2005; Tokem, 2006; Kav et al., 2008). For that reason, it is stated that there is a need randomized controlled studies with high level of evidence, systematic literature reviews and meta-analyzes regarding the efficiency of CAM practices (Can, 2013).

In this article, researches carried out with gynecologic cancer patients using CAM are reviewed and it is aimed to provide a source for the researchers in the field by discussing which CAM method is used for which purpose, patients' perceptions on the effects/side effects occurred during/after using CAM and their sources of information regarding CAM.

\section{Materials and Methods}

This literature review has been composed of the period between January 2000 and March 2015 by using Scopus, Dynamed, Med-Line, Science Direct, Ulakbim,

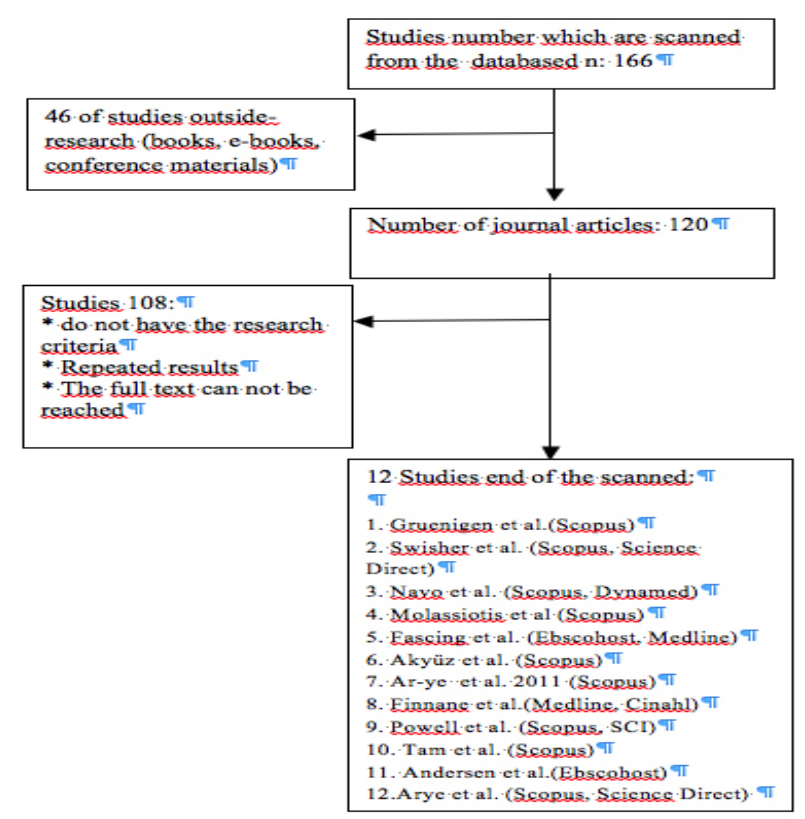

Figure 1. Study Design
Research Starters, Ebscohost, Cinahl Complete, Academic Onefile, Directory of Open Access Journals, Bmj Online Journals (2007-2009), Ovid, Oxford Journal, Proquest Hospital Collection, Springer-Kluwer Link, Taylor \& Francis, Up To Date, Web Of Science (Citation Index), Wiley Cochrane-Evidence Base, Wiley Online Library, and Pub-Med search databases with "complementary and alternative medicine, gynecologic cancer" as keywords. We were reached 32 articles from Science Citation Index (SCI) at, 20 articles from Direct' Science, 16 articles from SCOPUS, 14 articles from Dynamed, 13 articles from Medline, 7 articles from SSCI, 6 articles from ULAKBİ, 5 articles from Research Starters', 38 articles from Ebscohost, 3 articles from Cinahl, 3 articles from Academic OneFile, 1 article from Directory of Open Access. After searching through these results, a total of 12 full length papers in English (Gruenigen et al., 2001; Powell et al., 2002; Swisher et al., 2002; Navo et al., 2004; Tam et al., 2005; Molassiotis et al., 2006; Fascing et al., 2007; Akyuz et al., 2007; Finnane et al., 2011; Andersen et al., 2012; Arye et al., 2012; Arye-Ben et al., 2014). Studies which are fulfilling the criteria for this review through such studies obtained from the databased are shown in Figure 1.

Year and location of studies, number and specifications of samples, working method, features of users, CAM prevalence, type of CAM used, source of information, patients' thoughts on its efficiency, suggestions of the authors and important results obtained were evaluated. Qualitative studies and studies which do not meet three and more evaluation criteria are excluded.

\section{Results}

When the locations where the studies are carried out

Table 1. Classification of CAM Applications by NCCAM

Mind-body medicine

Mind-body systems

Mind-body methods (such as yoga)

Religious and spiritual healing

Social fields (such as holistic nursing)

Alternative medical systems

Acupuncture

Ayurvedic medicine

Traditional Chinese medicine

Naturopathic

Biyolojiye dayalı tedaviler

Herbals

Special dietary treatments

Pharmacological, biological interventions

Manipulative and body-based systems

Chiropractor

Massage

Osteopathy

Hydrotherapy

Energy therapies

a) Bioavailability

Therapeutic touch

Reflexology

b) Biyoelektromagnetik

The use of electromagnetic fields for medical purposes 
Use of Complementary and Alternative Medicine in Patients with Gynecologic Cancer: a Systematic Review Table 2. Features of Researches-I

\begin{tabular}{|c|c|c|c|c|c|c|c|c|}
\hline Authors & Sample & $\begin{array}{l}\text { Type of } \\
\text { research }\end{array}$ & $\begin{array}{l}\text { Type of } \\
\text { CAM }\end{array}$ & $\begin{array}{c}\text { Reason of using } \\
\text { CAM }\end{array}$ & Effects & $\begin{array}{c}\text { Feature of } \\
\text { users }\end{array}$ & $\begin{array}{l}\text { Source of } \\
\text { information }\end{array}$ & Limitations of researches \\
\hline $\begin{array}{l}\text { Gruenigen et } \\
\text { al. 2001 } \\
\text { USA }\end{array}$ & $\begin{array}{l}\mathrm{n}: 529 \\
\text { Gynecological } \\
\text { patients } \\
(\mathrm{n}=368) \\
\text { j.oncology } \\
\text { patients } \\
(\mathrm{n}=161) \\
\end{array}$ & Descriptive & $\begin{array}{l}56.3 \% \text { use of } \\
\text { CAM } \\
20 \% \text { dietary } \\
\text { supplement } \\
16 \% \\
\text { Exercise }\end{array}$ & $\begin{array}{l}\text { Useful in the } \\
\text { treatment } \\
\text { of the cancer } \\
\text { disease. }\end{array}$ & $\begin{array}{l}68 \% \text { of } \\
\text { patients in } \\
\text { gynecology } \\
\text { is in fact } \\
\text { beneficial }\end{array}$ & $\begin{array}{c}\text { Age and } \\
\text { education } \\
\mathrm{p}<0.05 \\
\text { Oncology } \\
\text { patients used } \\
\text { more }\end{array}$ & $\begin{array}{l}39 \% \text { of } \\
\text { patientsare } \\
\text { Suggested } \\
\text { by the doctor } \\
\text { in any of } \\
\text { TAT }\end{array}$ & $\begin{array}{l}\text { * Physicians should ask their } \\
\text { patients-informed } \\
\text { * There is a need for further studies } \\
\text { of the efficacy and harms }\end{array}$ \\
\hline $\begin{array}{l}\text { Swisher et } \\
\text { al. } 2001 \\
\text { USA }\end{array}$ & $\mathrm{n}: 113$ & Descriptive & $\begin{array}{c}49.6 \% \text { use of } \\
\text { CAM } \\
26 \% \text { (herbal } \\
\text { medicine, } \\
\text { vitamin and } \\
\text { mineral) } \\
\text { (prayer, } \\
\text { meditation, } \\
\text { yoga) } \\
\% 7 \text { shark } \\
\text { bone }\end{array}$ & $\begin{array}{l}36 \% \text { of direct } \\
\text { battle with } \\
\text { cancer } \\
64 \% \text { to } \\
\text { strengthen } \\
\text { immunity } \\
44 \% \text { of physical } \\
\text { relaxation } \\
60 \% \text { to } \\
\text { Psychological } \\
\text { relief } \\
64 \% \text { to try every } \\
\text { possibility }\end{array}$ & $\begin{array}{c}67 \% \text { hope } \\
\text { / positive } \\
\text { thinking } \\
64 \% \text { of } \\
\text { physical } \\
\text { well-being } \\
\text { There is no } \\
\text { benefit of } \\
4 \%\end{array}$ & $\begin{array}{c}\text { All users } \\
\text { access the pre- } \\
\text { diagnostic, } \\
\text { More religious } \\
\text { self-perceived, } \\
\text { Those high- } \\
\text { income level, } \\
\text { Ovarian } \\
\text { cancer more } \\
\text { than those } \\
\text { using }\end{array}$ & $\begin{array}{l}\text { \%6.8 doctor } \\
\% 9.8 \text { nurse }\end{array}$ & $\begin{array}{l}\text { * Standard clinic to receive treatment } \\
\text { arrivals-the results can not be } \\
\text { generalized } \\
\text { * High-rate at the beginning of } \\
\text { treatment the patient talk to the } \\
\text { doctor to inform the use of CAM }\end{array}$ \\
\hline $\begin{array}{c}\text { Navo et al. } \\
2004 \\
\text { USA }\end{array}$ & $\begin{array}{l}\mathrm{n}: 250 \text { breast } \\
\text { cancer } \\
\text { patients, } 250 \\
\text { Gynecological } \\
\text { oncology } \\
\text { patients }\end{array}$ & $\begin{array}{l}\text { Prospective } \\
\text { cohort }\end{array}$ & $\begin{array}{l}48 \% \% \text { use } \\
\text { of CAM } \\
29 \% \text { of } \\
\text { vitamin E } \\
1.6 \% \text { of the } \\
\text { root of } \\
\text { the Turkish } \\
\text { revant }\end{array}$ & $\begin{array}{l}55 \%-61 \% \text { to } \\
\text { improve the } \\
\text { overall } \\
\text { health / } \\
\text { life quality } \\
\text { improvement }\end{array}$ & $\begin{array}{l}\% 60 \text { safety } \\
\text { and benefit }\end{array}$ & $\begin{array}{l}\text { No statistically } \\
\text { significant } \\
\text { difference } \\
\text { between } \\
\text { the use of } \\
\text { ethnicity } \\
\text { Education p } \\
<0.05\end{array}$ & $\begin{array}{c}56 \% \text { of } \\
\text { health care } \\
\text { professionals } \\
63 \% \text { of } \\
\text { oncologists }\end{array}$ & $\begin{array}{l}\text { * Patients using CAM hide } \\
\text { * Language barrier } \\
\text { * They were suffering from anxieties } \\
\text { because of cancer, effectively answer } \\
\text { the research questions can influence } \\
\text { psychological states. }\end{array}$ \\
\hline $\begin{array}{l}\text { Molassiotis } \\
\text { et al. 2006 } \\
\text { Sweden } \\
\text { Serbia } \\
\text { Greece } \\
\text { Spain } \\
\text { Israel } \\
\text { England } \\
\text { Denmark } \\
\text { Turkey } \\
\text { Czech } \\
\text { republic } \\
\text { Switzerland. }\end{array}$ & $\mathrm{n}: 72$ & $\begin{array}{l}\text { Descriptive- } \\
\text { Cross- } \\
\text { sectional }\end{array}$ & $\begin{array}{c}40.3 \% \text { use of } \\
\text { CAM } \\
28.6 \% \\
\text { Relaxation } \\
\text { techniques } \\
\% 27.5 \\
\text { Herbal } \\
\text { medicine } \\
10.7 \% \\
\text { Acupuncture } \\
3.4 \% \\
\text { Spiritual } \\
\text { therapies }\end{array}$ & $\begin{array}{l}58.6 \% \text { increase } \\
\text { body resistance } \\
\text { (Physical } \\
(51.7 \%) \\
\text { and emotional } \\
\text { favors }(48.3) \text { ) } \\
20.7 \% \text { of } \\
\text { the help and } \\
\text { alleviate pain } \\
13.8 \% \text { to } \\
\text { counteract the } \\
\text { impact } \\
\text { of the disease } \\
3.4 \% \text { in cancer } \\
\text { battle }\end{array}$ & $\begin{array}{c}\% 10.3 \text { no } \\
\text { benefit } \\
\% 80.7 \\
\text { benefit }\end{array}$ & - & $\begin{array}{c}55.2 \% \\
\text { Friends } \\
27.6 \% \text { of } \\
\text { family } \\
24.1 \% \text { of } \\
\text { media, } \\
\text { newspapers, } \\
\text { magazines, } \\
\text { TV }\end{array}$ & $\begin{array}{l}\text { * Sample limited } \\
\text { * Patient records are not complete } \\
\text { * Specialized studies in Europe under } \\
\text { the name of gynecologic cancer are } \\
\text { rare. }\end{array}$ \\
\hline
\end{tabular}

Table 3. Features of researches-II

\begin{tabular}{|c|c|c|c|c|c|c|c|c|}
\hline Authors & Sample & $\begin{array}{l}\text { Type of } \\
\text { research }\end{array}$ & Type of CAM & $\begin{array}{l}\text { Reason of using } \\
\text { CAM }\end{array}$ & Effects & Feature of users & $\begin{array}{l}\text { Source of informa- } \\
\text { tion }\end{array}$ & Limitations of researches \\
\hline $\begin{array}{l}\text { Fasching } \\
\text { et al. } \\
2007 \\
\text { Germany }\end{array}$ & $\begin{array}{c}\mathrm{n}: 1030 \\
\text { (234:Gynecological } \\
\text { oncology patients) }\end{array}$ & $\begin{array}{l}\text { Cross- } \\
\text { sectional }\end{array}$ & $\begin{array}{c}44 \% \text { use of CAM } \\
79.6 \% \text { dietary techniques } \\
56.3 \% \text { of the immune } \\
\text { system booster drugs }\end{array}$ & $\begin{array}{l}\text { To improve the } \\
\text { quality of life }\end{array}$ & $\begin{array}{l}44.9 \% \text { of them } \\
\text { have side effects } \\
\text { There are } 9.8 \% \\
\text { growth }\end{array}$ & - & $\begin{array}{c}39.6 \% \text { of physicians } \\
49.3 \% \text { Friends and } \\
\text { family }\end{array}$ & $\begin{array}{l}\text { * Sample limited * TAT } \\
\text { on the effects of physical } \\
\text { and psychological status of } \\
\text { patients can be completed } \\
\text { well before the forms }\end{array}$ \\
\hline $\begin{array}{l}\text { Akyuz et } \\
\text { al. } 2007 \\
\text { Turkey }\end{array}$ & n: 126 & $\begin{array}{l}\text { Cross- } \\
\text { sectional }\end{array}$ & $\begin{array}{l}\text { 92\% use of CAM } \\
\text { 94.7\% praying } \\
95.1 \% \text { worshipping } \\
43.3 \% \text { Dreaming, } \\
\text { animating on eyes } \\
\text { 6.0\% Psychologic } \\
\text { therapies } \\
\text { (rely on therapy, belief } \\
\text { in healing) } \\
\text { 5.3\% Therapeutic touch } \\
\text { 4.3\% Aromatherapy } \\
\text { (lavender oil) }\end{array}$ & $\begin{array}{l}100 \% \text { Using/ } \\
\text { defining plants are } \\
\text { safe and useful } \\
87.5 \% \text { Using/ } \\
\text { psychologically } \\
\text { relaxing }\end{array}$ & $\begin{array}{c}* \text { Using/thinking } \\
\text { it to be beneficial } \\
94.8 \% * \text { Using/ } \\
\text { thinking it not } \\
\text { to be beneficial } \\
66.6 \%\end{array}$ & $\begin{array}{l}\text { * Patients using any type } \\
\text { of CAM were } \\
\text { younger and more } \\
\text { educated, } \\
\text { * There were no } \\
\text { significant } \\
\text { differences between the } \\
\text { patients who used and } \\
\text { who did } \\
\text { not use any type of } \\
\text { CAM with respect to } \\
\text { geographical region }\end{array}$ & $\begin{array}{c}97.8 \% \text { media } 86.9 \% \\
\text { relatives/friends }\end{array}$ & - \\
\hline $\begin{array}{l}\text { Arye et } \\
\text { al. } 2011 \\
\text { Israel }\end{array}$ & $\begin{array}{c}\text { n: } 275 \text { (109 } \\
\text { Gynecological } \\
\text { oncology patients) }\end{array}$ & Descriptive & $\begin{array}{c}63 \% \text { use of CAM } \\
\text { Generally, acupuncture, } \\
\text { relaxation exercises, } \\
\text { meditation, healing } \\
\text { plants used }\end{array}$ & $\begin{array}{l}\text { Reduce the } \\
\text { side effects of } \\
\text { chemotherapy } \\
\text { Provide as } \\
\text { emotional and } \\
\text { emotional support }\end{array}$ & $\begin{array}{l}\text { Thought to be } \\
\text { reassuring }\end{array}$ & $\begin{array}{l}\text { CAM users } \\
95 \% \text { of the Jews, } \\
67 \% \text { of university / } \\
\text { higher educated. } \\
\text { CAM users } \\
95 \% \text { of the Jews, } \\
67 \% \text { of university / } \\
\text { higher educated. }\end{array}$ & $\begin{array}{l}\text { Many of our } \\
\text { users and the } \\
\text { family physician } \\
\text { counseling took } \\
\text { oncologyist }\end{array}$ & $\begin{array}{c}\text { * Sample limited * } \\
\text { CAM use may affect } \\
\text { sociodemographic features } \\
\text { the deeper causes should be } \\
\text { investigated. }\end{array}$ \\
\hline $\begin{array}{l}\text { Finnane } \\
\text { et al. } \\
2011 \\
\text { Australia }\end{array}$ & $\begin{array}{l}\text { n: } 95 \text { women } \\
\text { diagnosed with } \\
\text { lipidemia's patients } \\
\text { of gynecological } \\
\text { and breast cancer } \\
\text { Gynecological } \\
\text { oncology } \\
\text { patients: } 15\end{array}$ & $\begin{array}{l}\text { Cross- } \\
\text { sectional }\end{array}$ & $\begin{array}{l}45 \% \text { use of CAM } \\
86 \% \text { of massage } \\
5-11 \% \text { selenium, } \\
\text { spiritual healing, } \\
\text { reiki, natural medicine } \\
\text { practices, acupuncture }\end{array}$ & - & $\begin{array}{l}\text { Perceived to be } \\
\text { effective. }\end{array}$ & $\begin{array}{l}64 \text { years and under, } \\
\text { and no significant } \\
\text { relationship was found } \\
\text { between the incidence } \\
\text { of breast cancer related } \\
\text { LE CAM use with the } \\
\text { participants }\end{array}$ & - & $\begin{array}{l}\text { * TAT kind of treatment, are } \\
\text { shown in the form. }\end{array}$ \\
\hline
\end{tabular}

are reviewed; five studies were carried out in the United States of America, 3 in European countries, 2 in Israel, 1 in China/Hong Kong and 1 in Australia (Table 1). 6 studies were definitive, 4 were cross-sectional, 1 was cohort and
1 was pragmatic observational. In these studies, 1978 women who were diagnosed with gynecologic cancer who use CAM were reached. CAM use in gynecologic cancer patients was discussed in 8 studies and CAM use 


\begin{tabular}{|c|c|c|c|c|c|c|c|c|}
\hline Authors & Sample & $\begin{array}{l}\text { Type of } \\
\text { research }\end{array}$ & Type of CAM & $\begin{array}{l}\text { Reason of using } \\
\text { CAM }\end{array}$ & Effects & $\begin{array}{c}\text { Feature of } \\
\text { users }\end{array}$ & $\begin{array}{l}\text { Source of } \\
\text { information }\end{array}$ & $\begin{array}{l}\text { Limitations of } \\
\text { researches }\end{array}$ \\
\hline $\begin{array}{l}\text { Powell et } \\
\text { al. } 2002 \\
\text { USA }\end{array}$ & $\begin{array}{c}\text { n: } 113 \text { Women } \\
\text { who were } \\
\text { diagnosed with } \\
\text { ovarian cancer }\end{array}$ & Descriptive & $\begin{array}{c}51 \% \text { use of CAM } \\
52 \% \text { soy products } \\
52 \% \text { ginseng } \\
43 \% \text { ginger } \\
43 \% \text { garlic } \\
24 \% \text { mushrooms } \\
24 \% \text { Black snake } \\
\text { root }\end{array}$ & $\begin{array}{l}\text { To reduce the } \\
\text { side effects of } \\
\text { chemotherapy }\end{array}$ & - & $\begin{array}{c}\text { More young } \\
\text { people have } \\
\text { used CAM }\end{array}$ & $52 \%$ doctors & - \\
\hline $\begin{array}{l}\text { Tam et al. } \\
2005 \text { China, } \\
\text { Hong Kong }\end{array}$ & $\begin{array}{c}\mathrm{n}: 191 \\
\text { Gynecological } \\
\text { oncology } \\
\text { patients }\end{array}$ & Descriptive & $\begin{array}{c}46.6 \% \text { use of } \\
\text { CAM } \\
\text { 71.9\% of herbal } \\
\text { medicines } \\
36 \% \text { diet, } \\
\text { nutrition } \\
\text { programs } \\
21.3 \% \text { chemical } \\
\text { agents } \\
2.2 \% \text { Acupuncture } \\
2.2 \% \text { reflexology }\end{array}$ & $\begin{array}{l}\text { For treatment of } \\
\text { complications } \\
\text { and side effects } \\
\text { of cancer therapy }\end{array}$ & - & $\begin{array}{c}(60.7 \%) \text { early } \\
\text { stage (stage } \\
1-2) \\
84 \% \text { surgery } \\
46.1 \% \\
\text { university } \\
34.8 \% \text { were } \\
\text { housewives }\end{array}$ & $\begin{array}{c}15 \% \text { general } \\
\text { gynecologists } \\
22.5 \% \\
\text { oncologists } \\
7.5 \% \text { family } \\
\text { doctors } \\
42.5 \% \text { from } \\
\text { herbalists }\end{array}$ & $\begin{array}{c}\text { Participants } \\
\text { know nurses } \\
\text { who practice } \\
\text { / study with } \\
\text { them } \\
\text { Some patients } \\
\text { had completed } \\
\text { treatment } \\
\text { years ago. }\end{array}$ \\
\hline $\begin{array}{c}\text { Andersen } \\
\text { et al. } 2012 \\
\text { USA }\end{array}$ & $\begin{array}{l}\mathrm{n}: 219 \text { overian } \\
\text { cancer }\end{array}$ & $\begin{array}{l}\text { Cross-sec- } \\
\text { tional }\end{array}$ & $\begin{array}{l}80 \% \text { use of CAM } \\
17 \% \text { fish oil } \\
12 \% \text { vitamin-E } \\
8 \% \text { of linseed oil } \\
<1 \% \text { gingko } \\
\text { yoga } \\
\text { meditation }\end{array}$ & $\begin{array}{l}33 \% \text { to } \\
\text { prevent from } \\
\text { complications } \\
\text { after surgery }\end{array}$ & - & $\begin{array}{c}37 \% \\
\text { university } \\
26 \% \\
\text { technical } \\
\text { schools } \\
19 \% \text { graduate } \\
51 \% \text { stage III } \\
\text { Generally } \\
\text { more young } \\
\text { participants }\end{array}$ & $\begin{array}{c}18,4 \% \text { doctor } \\
18,4 \% \\
\text { herbalists }\end{array}$ & - \\
\hline $\begin{array}{l}\text { Arye et al. } \\
2014 \text { Israel }\end{array}$ & $\begin{array}{l}\text { n: } 238 \text { women } \\
58 \text { women } \\
(24.8 \%) \\
\text { gynecological } \\
\text { cancer ( } 38 \\
\text { ovarian cancer, } \\
17 \text { endometrial } \\
\text { cancer, } \\
\text { cervical cancer } \\
4)\end{array}$ & $\begin{array}{c}\text { Pragmatic } \\
\text { prospective } \\
\text { observational }\end{array}$ & $\begin{array}{c}69.5 \% \text { use of } \\
\text { CAM Herbal } \\
\text { remedies, } \\
\text { acupuncture, } \\
\text { arthroscopic } \\
\text { drugs, relaxation, } \\
\text { music therapy, } \\
\text { spiritual } \\
\text { counseling }\end{array}$ & $\begin{array}{l}\text { 21.3\% To reduce } \\
\text { side effects of } \\
\text { chemotherapy, } \\
21 \% \text { To prevent } \\
\text { weight loss } \\
\text { 19.8\% To prevent } \\
\text { fatigue } \\
\text { 16.4\% emotional } \\
\text { / spiritual support } \\
8.4 \% \text { To resolve } \\
\text { pain } \\
\text { 0.8\% To resolve } \\
\text { dermatological } \\
\text { symptoms }\end{array}$ & $\begin{array}{c}\text { Tthere was no } \\
\text { effect in } 18.6 \% \text { of } \\
\text { patients, } \\
\text { But CAM has } \\
\text { reduced the } \\
\text { toxicity of } \\
\text { chemotherapy } \\
28.8 \% \text { of patients } \\
\text { and } \\
\text { reduced the } \\
\text { fatigue of } 17.9 \% \\
\text { of patients and } \\
\text { reduced emotional } \\
\text { distress of the } \\
7.1 \% \text { of patients }\end{array}$ & $\begin{array}{l}\text { The average } \\
\text { age } 62.42 \\
\text { The } 82.8 \% \\
\text { of patients } \\
\text { language } \\
\text { were Hebrew }\end{array}$ & $\begin{array}{c}49.2 \% \text { nurses } \\
10.2 \% \text { of } \\
\text { doctor / } \\
\text { oncologist }\end{array}$ & $\begin{array}{l}\text { Sample } \\
\text { limited }\end{array}$ \\
\hline
\end{tabular}

in breast and gynecologic cancer patients was discussed in 4 studies. It was determined that the frequency of CAM use varies between $40.3 \%$ and $94.7 \%$ and used of CAM was lowest in the study no 4 carried out in European countries $(40.3 \%)$ and highest in the study no 6 carried out in Turkey (94.7\%).

As the CAM method, herbal medicines, vitamins/ minerals were used most frequently in 8 of the studies (1, $2,3,5,9,10,11$ and 12). While $27.5 \%$ of the gynecologic cancer patients used herbal treatment in the study no 4 , $3.4 \%$ preferred spiritual therapy method. In the study no 6 which was carried out in Turkey, it was determined that $94.7 \%$ of the patients preferred praying and $4.3 \%$ preferred aromatherapy as CAM method. In the studies no 7 and 8 , mostly touching therapies and massage were used as CAM method.

When the reasons why gynecologic cancer patients use CAM are examined, it is determined that they use to strengthen the immune system, reduce the side effects of cancer treatment and physical and psychological relaxation in studies no $2,4,7,9,10,11$ and 12 . While it is stated that gynecologic cancer patients use CAM to increase their life quality in studies no 3 and 5, it was determined in study no 6 that all of the patients use CAM as they think herbal treatments more reliable than medical treatments and such treatments provide psychological relaxation.

When the benefit-damage perception of the patients after CAM use is examined, it is determined that most of the patients perceive CAM as beneficial (72\% in study no $1,96 \%$ in study no $2,60 \%$ in study no $3,94.8 \%$ in study no 6 and all of them in studies no 7 and 8). In study no $12,28.8 \%$ of the patients who use CAM stated that it reduces the toxicity of chemotherapy, $17.9 \%$ stated that it reduces fatigue, $7.1 \%$ stated it reduces emotional problems. However, $4 \%$ of the patients in study no 2 and $10.3 \%$ in study no 4 stated that using CAM has no benefit and $44.9 \%$ in study no 5 stated that side effects are seen after CAM use.

When the features of gynecologic cancer patients using CAM are examined, statistically significant relation was determined between the use of CAM and age and education in study no 1 . In study no 2 , it was determined that people who use CAM before being diagnosed with cancer, who reckon themselves as more religious, who have higher incomes and have ovary cancer use CAM 
more frequently. In study no 3 , no significant relation was determined between the ethnicity of the patients and the use of CAM. In studies no 6, 9 and 11 , it was seen that patients using CAM are younger and have higher education levels. Among the CAM users, 67\% in study no 7 and $37 \%$ in study no 11 have undergraduate/graduate degree. In study no 8, a significant relation was determined between lymphedema in patients and using CAM.

The rate of patients who get the information regarding CAM from their friends is $33 \%$ in study no $2,55.2 \%$ in study no $4,49.3 \%$ in study no 5 and $59.4 \%$ in study no 6 . $39 \%$ of the patients in study no 1 and most of the patients in studies no 3, 7 and 9 stated that they get the information regarding CAM from a physician. $42.5 \%$ in study no 10 and $18.4 \%$ in study no 11 , patients get the information regarding CAM from herbalists.

When the limitations regarding the research on CAM use is examined, it was stated that the study no 2 was carried out with patients who came for cancer treatment, it is not possible to separate the results certainly for their relation to CAM or routine cancer treatment and the accuracy of the results might be weak. Limitations of the studies were determined as "hiding CAM use and language barrier" in study no 3, "low number of samples" in studies no 4, 5, 7 and 12 and "participants' being familiar with the nurses" in study no 10 . In addition, "patients' filling in the surveys while their general condition is good" is determined as the limitation of study in study no 5 .

In studies no 1 and 2, it was suggested that healthcare professionals should get in-depth information from the patients as most of the patients use CAM and method/ types of CAM are various. In study no 4, it was stated the number of studies specific to gynecologic cancer is low and related studies are required on the subject. In study no 7 ,it is emphasized that it is necessary to make an in-depth analysis of the socio-demographic characteristics of the patients as these affect their use of CAM.

\section{Discussion}

In this review, studies on women diagnosed with gynecologic cancer are examined and it is determined that the frequency of using CAM varies between $40.3 \%$ and $94.7 \%$. Horneber et al. determined the frequency of CAM use in the meta-analysis of studies carried out in 18 countries in America and Europe as $40 \%$ (Horneber et al., 2012). In this review, it is determined that herbal CAM method is used most frequently as a common orientation in eight studies and CAM method preferences vary regionally. For example, in the studies carried out it is found that massage and touch therapies are preferred in Australia and Israel, herbal products and medicines are preferred in Europe and America and praying is preferred in Turkey. As a result of 52 studies that Verhoef et al. reviewed in their systematic compilation, it is determined that cancer patients use CAM methods according to the religious preferences of the country they live in (Verhoef et al., 2005). In the light of these findings, it is thought that cancer patients use the methods related to the religious preferences which are frequently used in the area where they live and which they believe that they will relieve the stress and make them psychologically strong.

In most of the studies in this review, it is determined that gynecologic cancer patients use CAM to strengthen their immune system and increase their life quality. In studies which are carried out on overall cancer patients, patients stated that they use CAM with the purpose of protecting from other diseases and strengthen their immune system (Richirdson et al., 2004; Mao et al., 2011). According to this, it is seen that cancer patients use CAM not for medical treatment of the disease but as a supportive treatment with the purpose of eliminating symptoms, reducing side effects and strengthening immune system. This might be a positive sign as they do not reject medical treatment. However, as both treatments are carried out together, potential effects and side effects cannot be determined.

In this review, most of the gynecologic cancer patients perceive use of CAM as beneficial. Only in study no 5, $44.9 \%$ of the patients stated that there are side effects after using CAM. However, there are limitations to the responses of the patients on CAM. While patients use CAM together with medical treatment, they have difficulty in distinguishing the benefits or side effects of them. In addition, while CAM does not cause side effects alone, it might cause side effects together with medical treatment. In that respect, healthcare professionals are required to know the contents of CAM and medical treatment and provide consultancy on CAM use in accordance with the patient's history and medical treatment.

In this review, it is determined that gynecologic cancer patients using CAM are generally younger and have higher levels of education. Studies reviewed are generally carried out in developed countries. According to this, it is thought that educated young people easily access CAM sources in developed countries.

When information sources regarding CAM are examined in this review, patients stated that they have information from their friends in four studies and from their doctors in seven studies. According to the findings obtained, it is seen that one patient out of three gets the information from the doctor. In that respect, it is important that healthcare professionals (doctors, nurses and midwives, dieticians, psychologists, etc.) must have knowledge of CAM in terms of providing guidance/ consultancy to patients and patient relatives.

In this review, limitations stated in the studies are generally related to small size of samples, not being homogenous and about the reliability of the findings. The accuracy of self-reports on CAM use in face-to-face interviews might be biased by social desirability. In that respect, it is emphasized that randomized controlled reviews with broader samples are required to determine the efficiency of CAM.

This review has several limitations. The review was limited to publications in the English language; potentially relevant studies may therefore have been excluded. Pediatric and men populations were also excluded, limiting the generalizability of our conclusions. Many definitions of CAM are used in the literature. Keeping this in mind, we included all types of CAM in this review.

CAM is frequently used by patients diagnosed with 
gynecologic cancer as in other patients with cancer and various other diseases. Gynecologic cancer patients generally use CAM to reduce the side effects of medical treatment, strengthen the immune system and improve their overall condition. Studies with higher level of evidence regarding the efficiency/side effects of CAM methods and can be generalized to gynecologic cancer patients are required.

In order that the patients obtain adequate reliable information about CAM and avoid practices which may harm the efficiency of the medical treatment, it is recommended that "Healthcare Professionals" develop a common language. Moreover clear strategies should be developed how to further deal with prevalent health related behavior of gynecologic cancer patients.

\section{References}

Akyuz A, Dede M, Cetinturk A, et al (2007). Self-application of complementary and alternative medicine by patients with gynecologic cancer. Gynecol Obstet Invest, 64, 75-81.

Amanak K, Karaoz B, Sevil U (2013). Alternative / Complementary Medicine and Women's Health. TAF Prev Med Bulletin, 12, 441-8.

Andersen MR, Sweet ES, Lowe KA, et al (2012). Potentially dangerous complementary and alternative medicine (cam) use by overian cancer patients. J Gynecol Surg, 28, 116-20.

Arye- Ben E, Schiff E, Raz OG, et al (2014). Integrating a complementary medicine consultation for women undergoing chemotherapy. Int J Gynaecol Obstet, 124, 51-4.

Arye EB, Schiff E, Steiner M, et al (2012). Attitudes of patients with gynecological and breast cancer toward integration of complementary medicine in cancer care. Int J Gynecol Cancer, 22, 146-53.

Can G (2013). Complementary approaches in breast cancer: Non-pharmacological approaches. [Meme kanserinde tamamlayıcı yaklaşımlar: Non-farmakolojik Yaklaşımlar]. $J$ Be Healthy [Sağlıkla Hemşirelik Dergisi (Turkish Article)], 13, 54-5.

Fascing PA, Thiel F, Nicolaisen-Murmann K, et al (2007). Association of complementary with quality of life and life satisfaction in patients with gynecologic and breast malignancies. Support Care Cancer, 15, 1277-84.

Finnane A, Liu Y, Battistutta D, et al (2011). Lymphedema after breast or gynecological cancer: use and effectiveness of mainstream and complementary therapies. J Altern Complement Med, 17, 867-9.

Gruenigen VEV, White LJ, Kirven MS, et al (2001). A comparison of complementary and alternative medicine use by gynecology and gynecologic oncology patients. Int J Gynecol Cancer, 11, 205-9.

Gungormus Z, Kiyak E (2012). Evaluation of the knowledge, attitude and behaviors of individuals who suffer from pain towards complementary and alternative medicines. Agri, 24, 123-9.

Horneber M, Bueschel G, Dennert G, et al (2012). How many cancer patients use complementary and alternative medicine: a systematic review and meta analysis. Integr Cancer Ther, 11, 187-03.

International Childhood Cancer Day 2015. [Internet, World Health Organization Web Site]. [updated 2015 June 29]

Karayagiz-Muslu G, Ozturk C ( 2008). Complementary and alternative treatments and their practice in children. department of pediatric nursing, ege and dokuz eylul university nursing schools. Izmir, Turkey. Turk J Pediatr,
51, 62-7.

Kav S, Hanoglu Z, Algier L (2008). Use of complementary and alternative medicine by cancer patients in turkey: a literature review. Int J Hematol Oncol, 18, 32-8.

Lee MM, Lin SS, Wrensch MR, et al (2000). Alternative therapies used by women with breast cancer in four ethnic populations. J Natl Cancer Inst, 92, 42-7.

Manheimer E, Berman B (2003). NCCAM support for the Cochrane Collaboration CAM Field. Complementary Therapies in Med, 11, 268-271.

Mao JJ, Palmer CS, Healy KE, et al (2011). Complementary and alternative medicine use among cancer survivors: a population-based study. J Cancer Surviv, 5, 8-17.

Molassiotis AM, Milovics L, Pantelis V, et al (2006). Complementary and alternative medicine use in patients with gynecological cancers in Europe. Int J Gynecol Cancer, 16, 219-24.

Navo MA, Phan J, Vaughan C, et al (2004). Assessment of the utilization of complementary and alternative medication in women with gynecologic or breast malignancies. J Clin Oncol, 22, 671-7.

Powell CB, Dibble SL, Dallera JE, et al (2002). Use of herbs in women diagnosed with overian cancer. Int $J$ Gynecol Cancer, 12, 214-7.

Pud D, Kaner E, Morag A, et al (2005). Use of complementary and alternative medicine among cancer patients in Israel. Eur J Oncol Nurs, 9, 124-30.

Richirdson ME, Masse LC, Nanny K, et al (2004). Discrepant views of oncologists and cancer patients on complementary/ alternative medicine. Support Care Cancer, 12, 797-804.

Scott JA, Kearney N, Hummerston S, et al (2005). Use of complementary and alternative medicine in patients with cancer: A UK survey. Eur J Oncol Nurs, 9, 131-7.

Swisher E, Cohn D, Goff BA, et al (2002). Use of complementary and alternative medicine among women with gynecologic cancers. Gynecol Oncol, 84, 363-7.

Tam KF, Cheng KL, Ng TY, et al (2005). The behaviors of seeking a second opinion from other health-care professionals and the utilization of complementary and alternative medicine in gynecologic cancer patients. Support Care Cancer, 13, 679-84.

Tokem Y (2006). The use of complementary and alternative treatment in patients with asthma. Tuberk Toraks [Turkish Article], 54, 189-96.

Turan N, Ozturk A, Kaya N (2010). A new responsibility in nursing: complementary therapy. J Maltepe University Nursing Sci Art [serial online], 2, 103-8.

Upchurch DM, Chyu L (2005). Use of complementary and alternative medicine among American women. Womens Health Issues, 15, 5-13.

Verhoef MJ, Balneaves LG, Boon HS, et al (2005). Reasons for and characteristics associated with complementary and alternative medicine use among adult cancer patients: a systematic review. Integr Cancer Ther, 4, 274-86.

Wieland LS, Manheimer E, Berman BM (2011). Development and classification of an operational definition of complementary and alternative medicine for the cochrane collaboration. Altern Ther Health Med, 17, 50-9. 